\title{
Scaling net ecosystem production and net biome production over a heterogeneous region in the western United States
}

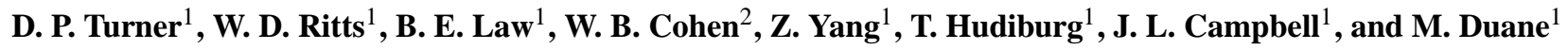 \\ ${ }^{1}$ Forest Science Department, Oregon State University, Corvallis OR 97331, USA \\ ${ }^{2}$ USDA Forest Service, PNW Station, Corvallis OR 97331, USA
}

Received: 22 March 2007 - Published in Biogeosciences Discuss.: 5 April 2007

Revised: 27 July 2007 - Accepted: 30 July 2007 - Published: 6 August 2007

\begin{abstract}
Bottom-up scaling of net ecosystem production (NEP) and net biome production (NBP) was used to generate a carbon budget for a large heterogeneous region (the state of Oregon, $2.5 \times 10^{5} \mathrm{~km}^{2}$ ) in the western United States. Landsat resolution $(30 \mathrm{~m})$ remote sensing provided the basis for mapping land cover and disturbance history, thus allowing us to account for all major fire and logging events over the last 30 years. For NEP, a 23-year record (1980-2002) of distributed meteorology (1 km resolution) at the daily time step was used to drive a process-based carbon cycle model (Biome-BGC). For NBP, fire emissions were computed from remote sensing based estimates of area burned and our mapped biomass estimates. Our estimates for the contribution of logging and crop harvest removals to NBP were from the model simulations and were checked against public records of forest and crop harvesting. The predominately forested ecoregions within our study region had the highest NEP sinks, with ecoregion averages up to $197 \mathrm{gC} \mathrm{m}^{-2} \mathrm{yr}^{-1}$. Agricultural ecoregions were also NEP sinks, reflecting the imbalance of NPP and decomposition of crop residues. For the period 19962000, mean NEP for the study area was $17.0 \mathrm{TgC} \mathrm{yr}^{-1}$, with strong interannual variation (SD of 10.6). The sum of forest harvest removals, crop removals, and direct fire emissions amounted to $63 \%$ of NEP, leaving a mean NBP of $6.1 \mathrm{TgC} \mathrm{yr}^{-1}$. Carbon sequestration was predominantly on public forestland, where the harvest rate has fallen dramatically in the recent years. Comparison of simulation results with estimates of carbon stocks, and changes in carbon stocks, based on forest inventory data showed generally good agreement. The carbon sequestered as NBP, plus accumulation of forest products in slow turnover pools, offset $51 \%$ of the annual emissions of fossil fuel $\mathrm{CO}_{2}$ for the state. Statelevel NBP dropped below zero in 2002 because of the combination of a dry climate year and a large (200000 ha) fire.
\end{abstract}

Correspondence to: D. P. Turner

(david.turner@oregonstate.edu)
These results highlight the strong influence of land management and interannual variation in climate on the terrestrial carbon flux in the temperate zone.

\section{Introduction}

Efforts to locate and explain the large terrestrial carbon sinks inferred from inversion studies (Baker et al., 2006; Bousquet et al., 2000) are faced with accounting for spatially extensive factors like climate variation and $\mathrm{CO}_{2}$ increase (Schimel et al., 2000), fine scale phenomena associated with anthropogenic and natural disturbances (Korner, 2003; Pacala et al., 2001), and temporal variation at the seasonal and interannual scales. Carbon budget approaches based on forest inventory information, e.g. Kauppi et al. (1992), are poorly resolved spatially and temporally, do not reveal the mechanisms accounting for changes in carbon stocks, and miss carbon flux associated with non-forest vegetation. Alternatively, a process modeling approach - with inputs of high spatial resolution remote sensing data and distributed meteorological data - can provide estimates of net ecosystem production (NEP, sensu Lovett et al., 2006) for potential comparison with NEP fluxes from inverse modeling studies, and provide estimates of net biome production (NBP, sensu Schulze et al., 2000) for comparison with carbon accounting being done in support of the Framework Convention on Climate Change (UNFCCC, 1992). In this analysis, we apply a process modeling approach to generate a carbon budget over the state of Oregon $\left(2.5 \times 10^{5} \mathrm{~km}^{2}\right)$ in western North America between 1980 and 2002. The period included a significant reduction in forest harvesting on public lands, several extreme climate years, and an exceptional fire year.

The forests of the Pacific Northwest region of the United States (U.S.) are of particular interest with regard to terrestrial carbon flux because of their high biomass and productivity (Smithwick et al., 2003; Waring and Franklin, 1979),

Published by Copernicus Publications on behalf of the European Geosciences Union. 


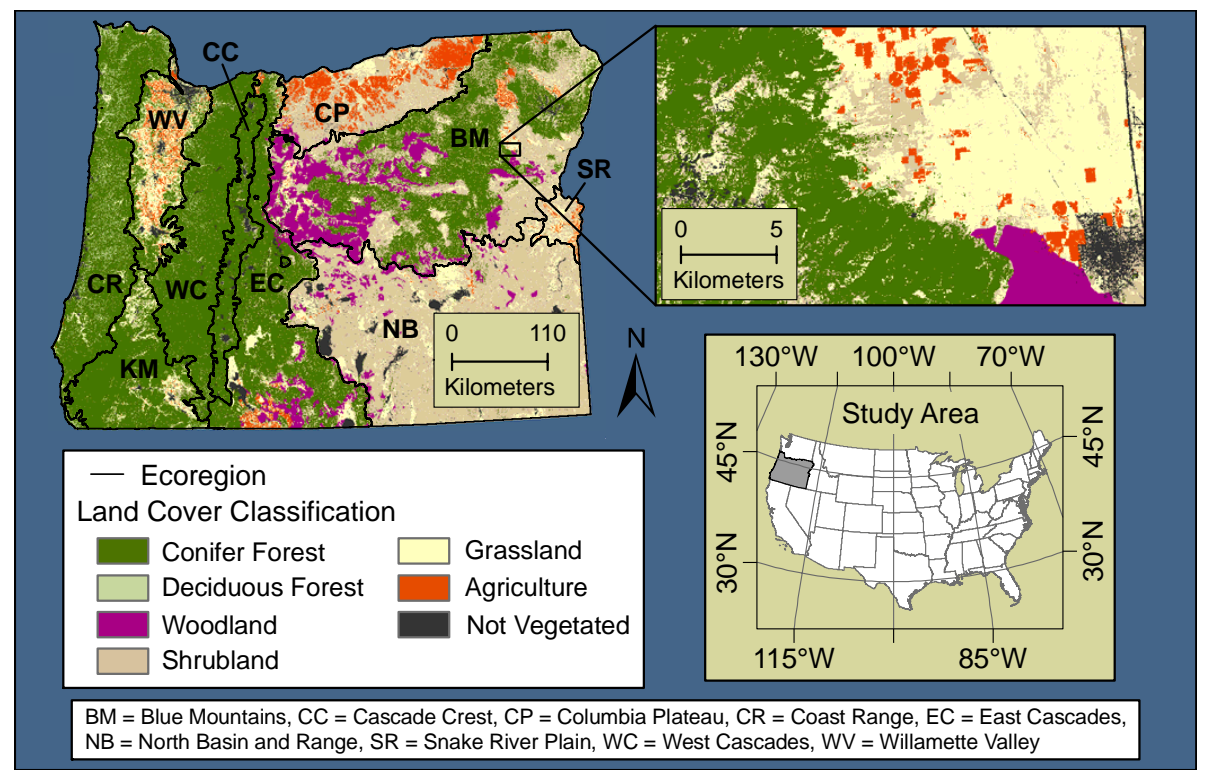

Fig. 1. Land cover map for Oregon with detail for a selected area.

the mixture of land ownerships with differing management objectives (Garman et al., 1999), the sensitivity of the forest carbon balance to interannual climate variation (Morgenstern et al., 2004; Paw U et al., 2004), and potential for increased incidence of stand replacing fires in association with projected climate change (Bachelet et al., 2001; Westerling et al., 2006). Earlier studies of carbon stocks and fluxes on forestlands in the region suggest that it is transitioning from a carbon source to a carbon sink (Cohen et al., 1996; Law et al., 2004; Wallin et al., 2007). Carbon flux in nonforest ecosystems of the region is less well studied. However, the high productivities and large carbon transfers at the time of harvest in agricultural areas, and the large areas of semi-natural vegetation cover, could potentially have strong influences on the regional carbon budget.

\section{Methods}

\subsection{Overview}

The primary NEP/NBP scaling tool in this analysis was the Biome-BGC model (Thornton et al., 2002) and details of its application for the purposes of scaling carbon pools and flux are given in previous publications (Law et al., 2004; Law et al., 2006; Turner et al., 2004; Turner et al., 2003). Generally, we used model simulations to produce spatially-explicit estimates of carbon stocks as well as estimates of annual net primary production (NPP), heterotrophic respiration $\left(\mathrm{R}_{h}\right)$, and net ecosystem production for each year from 1980 to 2002 over the state of Oregon. Annual NBP (NEP - harvest removals - pyrogenic emissions) was estimated from the simulated logging removals, crop harvest removals, and fire emis- sions. In our previous studies, we assumed all forest stands originated as a clear-cut of a secondary forests, but in this application we introduced the capacity to simulate one or two clear-cut or fire disturbances (based on remote sensing) as the simulation for a given grid cell is brought up to 2002 after model spin-up. We have also begun modeling all vegetation cover types, thus permitting wall-to-wall estimation of the carbon pools and fluxes.

\subsection{Land cover}

We first established a forest/nonforest coverage based on areas analyzed in our previous change detection studies (Law et al., 2004; Lennartz, 2005) Within the forest class, forest type was originally designated as evergreen conifer, deciduous broadleaf, or mixed. However, we reclassified mixed as conifer here because a mixed class was not supported in the Biome-BGC process model. We next overlaid a Juniper Woodland coverage from the Oregon GAP Analysis (Kagan et al., 1999). Lastly, we filled in all nonforest areas with the National Land Cover Data (NLCD) coverage (Vogelmann et al., 2001). These coverages were all based on Landsat imagery at the $30 \mathrm{~m}$ resolution. The Transitional Vegetation Class in the NLCD coverage, which is primarily regrowing clear-cuts, was reclassified as conifer forest. Other NLCD classes were aggregated to a simple 7 class scheme (Fig. 1). The final coverage was resampled to the $25 \mathrm{~m}$ resolution for ease of overlay with the $1 \mathrm{~km}$ resolution climate data. Ecoregions boundaries are from the scheme of Omernik (1987). 
Table 1. Landsat-based change detection analysis. Values are percentage of the total forest area in each disturbance class.

\begin{tabular}{|c|c|c|}
\hline Location & Disturbance & Percentage \\
\hline \multirow[t]{13}{*}{ Eastern Oregon } & Forest - no change & 83.6 \\
\hline & Cut 02-04 & 1.0 \\
\hline & Cut 94-01 & 5.0 \\
\hline & Cut 89-93 & 2.4 \\
\hline & Cut $85-88$ & 2.1 \\
\hline & Cut $75-84$ & 1.4 \\
\hline & Cut 73-76 & 0.8 \\
\hline & Fire $02-04$ & 0.4 \\
\hline & Fire 94-01 & 1.9 \\
\hline & Fire 89-93 & 1.2 \\
\hline & Fire $85-88$ & 0.1 \\
\hline & More than 1 disturbance in last 30 years & 0.2 \\
\hline & Total & 100.0 \\
\hline \multirow[t]{18}{*}{ Western Oregon } & Forest - no change & 78.3 \\
\hline & Cut 03-04 & 2.0 \\
\hline & Cut 01-02 & 1.0 \\
\hline & Cut 96-00 & 2.0 \\
\hline & Cut 92-95 & 1.9 \\
\hline & Cut 89-91 & 2.8 \\
\hline & Cut $85-88$ & 3.7 \\
\hline & Cut 78-84 & 3.9 \\
\hline & Cut 72-77 & 2.1 \\
\hline & Fire $03-04$ & 0.8 \\
\hline & Fire $01-02$ & 0.9 \\
\hline & Fire $96-00$ & 0.1 \\
\hline & Fire $92-95$ & 0.1 \\
\hline & Fire 89-91 & 0.0 \\
\hline & Fire $85-88$ & 0.3 \\
\hline & Fire $78-84$ & 0.0 \\
\hline & More than 1 disturbance in last 30 years & 0.1 \\
\hline & Total & 100.0 \\
\hline
\end{tabular}

\subsection{Forest stand age and disturbance history}

For each $25 \mathrm{~m}$ grid cell classified as forest, a disturbance history was formulated. These disturbance histories consisted of one or two disturbance events that were specified by year and type (fire or clear-cut harvest). Disturbances during the Landsat era (1972-2002) were mapped (Table 1, Fig. 2) using change detection based on wall-to-wall Landsat imagery every 2 to 5 years (Cohen et al., 2002; Healey et al., 2005; Lennartz, 2005). In our simulations, the disturbances were scheduled at the midpoint of each interval. Accuracy assessment of the stand replacement maps was conducted in Cohen et al. (2002) and reported as $88 \%$. Assumptions about what was present at the time of the first disturbance were ecoregion specific, e.g. in the Coast Range ecoregion the stand was assumed to be 75 years old to reflect the rotation age and the fact that much of the Coast Range had been harvested previous to the Landsat era (Garman et al., 1999).

For all conifer forestland in western Oregon that had no stand replacing disturbances during the Landsat era, stands were aged by classification into broad age classes (young, mature, old) using recent Landsat imagery (as in Cohen et al., 1995). The approach depends on spectral variation among stands of different ages associated with changes in stand structure. In eastern Oregon, it was not possible to age undisturbed stands using Landsat data because the stands are relatively open and often uneven aged. Thus for the ecoregions in the eastern part of the state, all conifer pixels $>30$ years of age were assigned the ecoregion specific, basal-areaweighted, median age (Waddell and Hiserote, 2005) from USDA Forest Service Forest Inventory and Analysis data (FIA, 2006). Our previous chronosequence studies (Campbell et al., 2004) in eastern Oregon have indicated that NEP remains positive over the course of mid and late succession in these relatively open stands, thus minimizing the error in NEP introduced by these assumed ages. As a sensitivity check, simulated NEP at a representative site and at the median age for each of these ecoregions was compared with the associated age-weighted mean NEP from Biome-BGC simulations based on the age distribution of all FIA permanent 


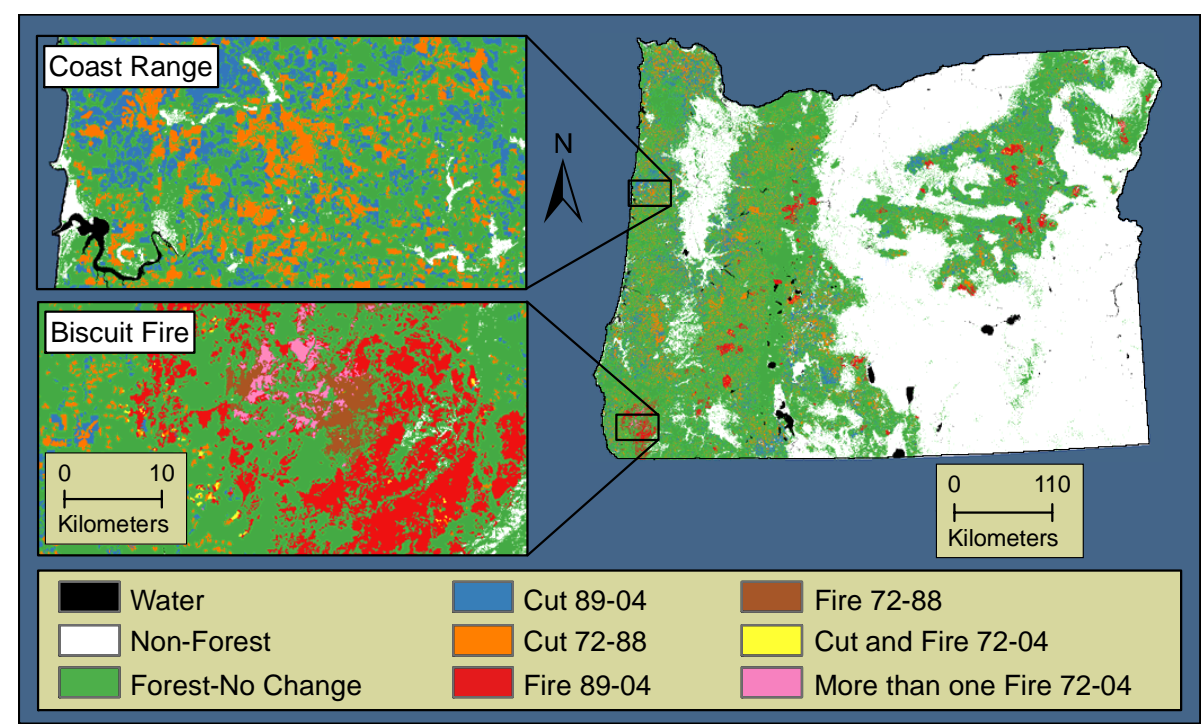

Fig. 2. Change detection map for Oregon with detail for selected areas.

plots in the ecoregion. Results did not indicate a strong bias (Table 2).

The deciduous broadleaf and mixed (reclassified as conifer) classes were assigned an age of 40 , reflecting limited information from inventory data and knowledge from the change detection analysis that these stands were $>30$ years old. Juniper woodlands were assigned an age of 70 based on the observation that many of these stands have originated since the late 1800s when heavy grazing and fire suppression began to promote juniper expansion in eastern Oregon (Gedney et al., 1999). As with the open conifer stands in eastern Oregon, these woodland stands apparently continue to accumulate stem carbon over long periods (Azuma et al., 2005) which helps minimize the error in estimating NEP.

\subsection{Climate and soil inputs}

The meteorological inputs to Biome-BGC are daily minimum and maximum temperature, precipitation, humidity, and solar radiation. We used a 23-year (1980-2002) time series at $1 \mathrm{~km}$ resolution developed with the DAYMET model (DAYMET, 2006; Hasenauer et al., 2003; Thornton et al., 2000; Thornton and Running, 1999; Thornton et al., 1997). These data were based on interpolations of meteorological station observations using a digital elevation model and general meteorological principles. The 23 -year record was recycled as needed during the model spin-ups. Soil texture and depth were specified (at the $1 \mathrm{~km}$ spatial resolution) from the U.S. Geological Survey coverages (CONUS, 2007) that were originally generated by linking soil survey maps of taxonomic types to soil pedon databases (Miller and White, 1998).

\subsection{Biome-BGC parameterization and application}

The parameterization of ecophysiological and allometric constants in Biome-BGC (Table A1) was cover type and ecoregion specific. The values used were based on the literature (e.g. Pietsch et al., 2005; White et al., 2000), our field measurements (Law et al., 2004; Law et al., 2006), and our previous work with the model in this region (Turner et al., 2003, Law et al., 2004). Our field measurements (extensive plots) included over 100 plots in the study region that were distributed so as to sample the range of age classes within the conifer cover class in each ecoregion. The foliar nitrogen concentration and specific leaf area (SLA) measurements from these plots were used to specify foliar $\mathrm{C}$ to $\mathrm{N}$ ratio and SLA in the conifer class (Table 3). Earlier sensitivity analyses with Biome-BGC (White et al., 2000; Tatarinov and Cienciala, 2006), have revealed that the model is particularly sensitive to these parameters. Recent studies support the utilization of ecoregion-level reference data for model parameterization when it is available (Loveland and Merchant, 2004; Ogle et al., 2006).

As noted in Law et al. (2004), we have adapted BiomeBGC so that input parameters can be dynamic over the course of forest succession. Previously we used this feature to shift production belowground in late succession to reflect the age trends in bolewood production that are observed in FIA data (Law et al., 2006). Here, we have also made the mortality fraction a dynamic parameter (see Pietsch and Hasenauer, 2006) such that mortality may decrease over the course of succession. The range of mortality was made consistent with studies in the region (Acker et al., 2002; DeBell and Franklin, 1987; Lutz and Halpern, 2006). This feature was needed for simulating the forests of eastern Oregon which show sustained increases in biomass even in late succession (Camp- 
Table 2. Results of the sensitivity test for the effect of assuming all stands $>30 \mathrm{yr}$ are the median age from the forest inventory data. Weighted refers to the case in which the model was run once for each stand age and an age-weighted mean was determined based on the frequency distribution of the ages. Median refers to the case in which the model was run only at the median age.

\begin{tabular}{lcccccc}
\hline Ecoregion & \multicolumn{3}{c}{$\mathrm{NEP}\left(\mathrm{gC} \mathrm{m}^{-2} \mathrm{yr}^{-1}\right)$} & \multicolumn{3}{c}{ Woodmass $\left(\mathrm{kgC} \mathrm{m}^{-2}\right)$} \\
\hline & Weighted & Median & Difference & Weighted & Median & Difference \\
& Mean & & $(\%)$ & Mean & & $(\%)$ \\
East Cascades & 60 & 71 & 18 & 12.0 & 12.8 & 7 \\
Blue Mountains & 97 & 91 & 6 & 11.3 & 11.7 & 3 \\
\hline
\end{tabular}

Table 3. Ecoregion-specific values (conifer cover type) for foliar carbon to nitrogen ratio and specific leaf area. SD refers to standard deviation.

\begin{tabular}{lcccc}
\hline Location & \multicolumn{2}{c}{ Specific leaf area $\left(\mathrm{m}^{2} \mathrm{kgC}^{-1}\right)$} & \multicolumn{2}{c}{$\mathrm{C}$ to N ratio } \\
\hline & Mean & SD & Mean & SD \\
Coast Range & 13.3 & 3.1 & 38 & 5 \\
West Cascades & 10.1 & 2.3 & 52 & 6 \\
Eastern Cascades & 8.2 & 5.5 & 52 & 4 \\
Klamath Mountains & 8.7 & 5.7 & 51 & 6 \\
Blue Mountains & 10.6 & 3.7 & 48 & 5 \\
\hline
\end{tabular}

bell et al., 2004; Van Tuyl et al., 2005). Another modification to Biome-BGC was to constrain the maximum daily interception, as discussed in Lagergren et al. (2006).

For a standard model run, a model spin-up was performed and the model was run forward through the simulated disturbances to the year 2002, with looping of the 23 years of climate data as needed. For non-forest, non-woodland cover types, a model spin-up was performed and it was run to near carbon steady state by 1980 so that its year-to-year variation in NEP primarily reflected the influence of climate variation. In the case of croplands and grasslands (hayfields), where carbon is removed in the form of harvesting, we included the removals in the Biome-BGC simulations as we ran up to the present, thus the NEP tended to balance the removals (i.e. these areas are carbon sinks in terms of NEP).

Because of the computational demands of the model spinups, it was impractical do an individual model run for each $25 \mathrm{~m}$ resolution grid cell in the study area. The $1 \mathrm{~km}$ resolution of the climate data is adequate to capture the effects of the major climatic gradients, but our earlier studies in this region have shown that the scale of the spatial heterogeneity associated with land management is significantly less that $1 \mathrm{~km}$ (Turner et al., 2000). Thus, the model was run once in each $1 \mathrm{~km}$ cell for each of the 5 most common combinations of cover type and disturbance history. For mapping the carbon fluxes, a weighted mean value was calculated for each $1 \mathrm{~km}$ cell. This procedure explicitly accounted for $97 \%$ of the study area.
2.6 Harvest removals and fire emissions for NBP estimation

Estimation of NBP requires information on carbon transfers off the land base in addition to NEP (Schulze et al., 2000). To quantify wood harvest removals we assumed that $65 \%$ of wood carbon was removed at the time of harvest (Turner et al., 1995). For a check on our simulated harvest removals, these values were summed to the state level and compared with harvest data from the Oregon Department of Forestry (ODF, 2006). The ODF volume data were converted to carbon mass using the carbon densities in Turner et al. (1995). For the year-specific NBP calculations, we partitioned the total simulated removals among the years in a given change detection interval by reference to the partitioning in the ODF volume data.

Crop removals must also be quantified for NBP and here we assumed $80 \%$ of aboveground biomass was removed annually on all cropland and grassland grid cells. This crop ratio approximates the crop ratios in U.S. Department of Agriculture National Agricultural Statistics Service (NASS) reports for Oregon (USDA, 2001).

Direct emissions from forest fire can be a large term in NBP estimates and here were based on the change detection analyses for area burned, on carbon stocks in the burned areas from the Biome-BGC modeling, and on transfer coefficients that quantified the proportion of each carbon stock that burned. We assumed $100 \%$ of foliar, fine root, and litter carbon was emitted, and 7\% of aboveground wood. These values are similar to those found in high burn severity areas of a 
Table 4. Carbon fluxes for Oregon. Values are state-level five-year means and standard deviations for the period 1996-2000. Units are $\mathrm{TgC} \mathrm{yr}^{-1}$.

\begin{tabular}{lll}
\hline Flux & Mean & SD \\
\hline Net ecosystem production & 17.0 & 10.6 \\
Timber harvest & 5.9 & 0.3 \\
Crop harvest & 4.8 & 0.4 \\
Fire emissions & 0.2 & 0.2 \\
NBP & 6.1 & 10.2 \\
\hline
\end{tabular}

large wildfire in our study area (Campbell et al., 2007). The remainder of the wood was transferred to the coarse woody debris pool. Again, for the year-specific NBP calculations we partitioned the direct fire flux among the years of the change detection interval by reference to the ratio of area burned in a given year to area burned over the interval from state-level burned area statistics (NWCC, 2004).

\subsection{Uncertainty assessment}

Estimates of carbon stocks are important in the simulation of harvest removals and fire emissions, as well as giving a general indication of model behavior. For an independent estimate of the regional carbon stocks on forest land, USDA Forest Service inventory data ( 8929 plots in Oregon) can be summarized at the county level. Allometry and carbon density factors are used to convert volumes to total tree carbon and reference is made to expansion factors associated with the plot-level data to account for the sampling scheme (Hicke et al., 2007). The uncertainty associated with inventory-based bolewood volume estimates over large areas such as counties in the U.S. is considered to be less than five percent (Alerich et al., 2004). Uncertainty about the allometry used to scale volume to biomass is also relatively low (Van Tuyl et al., 2005). For comparable values from our Biome-BGC simulations, we averaged simulated tree biomass (woodmass) in 1995 (the end of the last inventory cycle) over all forested areas within each county. For other cover types, limited comparisons were made between the simulated carbon stocks and observations in the literature.

Evaluation of carbon flux on forestland, at least in terms of tree NBP, can also be made based on forest inventory data. Aggregated inventory data in the U.S. are periodically reported in terms of cubic feet of bolewood volume per unit area (Smith et al., 2004) and NBP (for trees) can be estimated as the change in total stocks divided by the associated interval. For our comparisons we used a conversion factor of $6.4 \mathrm{kgC}$ per cubic foot and a ratio of tree carbon to bolewood carbon of 1.7 (Turner et al., 1995). For NEP, we have previously reported comparisons of our Biome-BGC simulations to field measurements at an eddy covariance flux tower and at chronosequence plots in the region (Law et al., 2004; Law et al., 2006). For cropland/grassland NPP and harvest removals, we made comparisons to USDA NASS statistics (USDA 2001) aggregated to the ecoregion scale.

It was not feasible to perform a formal uncertainty analysis for inputs and parameters of our state wide NEP simulations (e.g. using a Monte Carlo approach at each point and summing uncertainty across the domain) because of computational constraints, because we don't know the moments and distribution types for the multitude of parameters in BiomeBGC, and because the error sources are not spatially independent. However, it is worth noting that the NEP estimates for forestland are to some degree stabilized against model parameter values affecting rates of growth (carbon sinks) because high growth rates create relatively large carbon stocks which become large carbon sources when disturbed. Similarly, artificially high rates of decomposition would push up carbon sources in the short term after disturbance but, since the model maintains mass balance, the total amount of heterotrophic respiration would tend to be similar over a whole successional cycle even with lower base turnover rates for $\mathrm{R}_{h}$. A significant check on seasonal and annual NEP at the regional scale will become available as the density of $\mathrm{CO}_{2}$ measurements supporting inverse modeling efforts increases (Karstens et al., 2006). Here, we made a first order comparison with optimized terrestrial carbon flux estimates over Oregon from the Carbon Tracker inversion scheme (NOAA, 2007).

\section{Results and discussion}

\subsection{Five-Year mean flux estimates}

For assessing the recent carbon budget we report means and standard deviations (over years) for the 5-year period 1996-2000 (Table 4). This period was after harvest levels stabilized following the significant decrease in the early 1990s (Fig. 4) and before the relatively warm/dry climate years of 2001 and 2002 (2002 was the driest of the 23 year record). Over that interval, the Oregon land base was a strong NEP sink, with total NEP averaging $17.0 \pm 10.6 \mathrm{TgC} \mathrm{yr}^{-1}$ $\left(67 \pm 42 \mathrm{gC} \mathrm{m}^{-2} \mathrm{yr}^{-1}\right)$.

Our statewide NEP estimates contrast with those from approaches that do not explicitly treat the disturbance regime. Prognostic models, which have a spin-up and are run forward to the present on historical climate, report a smaller NEP sink in the region, e.g. averaging about $30 \mathrm{gC} \mathrm{m}^{-2} \mathrm{yr}^{-1}$ in the 1990s in the study of Woodward et al. (2001). The carbon sink in that simulation was driven by a small disequilibrium in the carbon pools associated with the increasing $\mathrm{CO}_{2}$ concentration. Diagnostic models, driven by contemporary observations of climate and surface greenness from remote sensing, show Oregon as a carbon source over the 


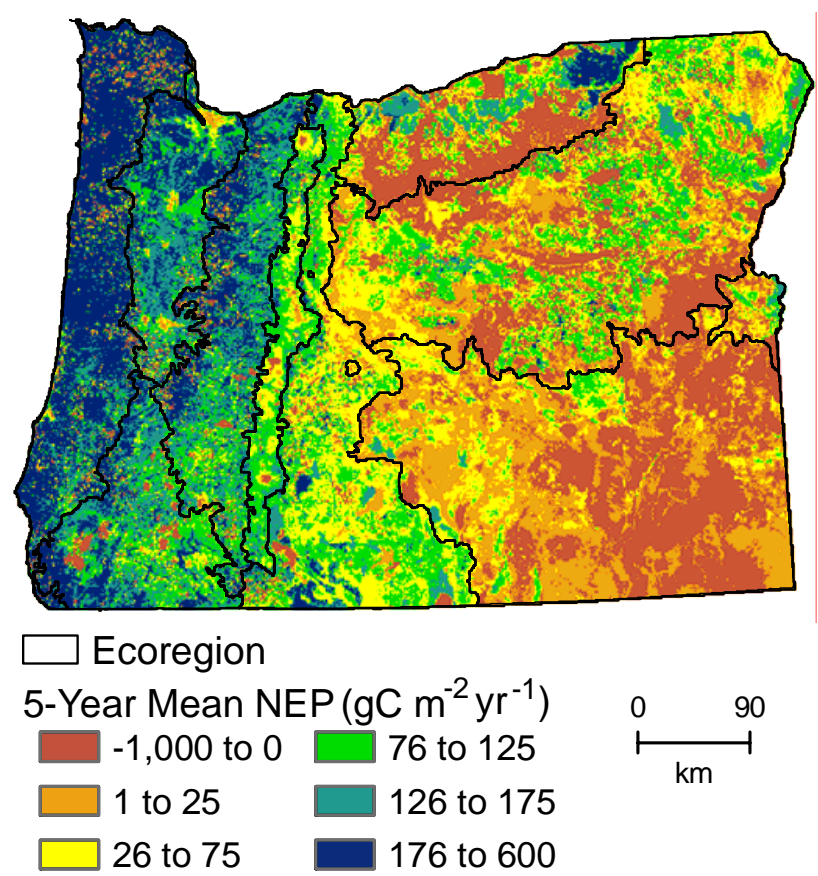

Fig. 3. The spatial distribution of net ecosystem production over Oregon. Values are 5-year means for the period 1996-2000.

period 1982-1997 (Potter et al., 2006), probably because of a warming trend (Mote, 2003).

The Coast Range and West Cascades ecoregions both had high mean NEP (Fig. 3, Table 5), but for different reasons. Forest productivity in the Coast Range is high because of the mild, mesic climate, and because intensive forest management for timber production has resulted in a relatively young age distribution at this time (Van Tuyl et al., 2005), thus high NEPs (Campbell et al., 2004). Because of less favorable climate, NPP at a given age is somewhat lower in the West Cascades ecoregion than in the Coast Range (Gholz, 1982). However, harvesting on public lands in Oregon (69\% of the forested land in the West Cascades ecoregion) was extensive in the decades leading up to the 1990s but has subsequently been restricted due to issues associated with the Northwest Forest Plan (Moeur et al., 2005). Much of the area harvested earlier is now a carbon sink and there is relatively little area on public lands that is a carbon source because of recent harvesting. The forests in eastern Oregon (EC and BM ecoregions) were a weak carbon sink from NEP, the net effect of relatively low NPP and NEP in a large area of undisturbed stands in a relatively xeric climate, and strong emissions in the areas subject to fire or harvest. In recent years, the proportion of forestland disturbed per year (harvest or fire) in eastern OR has been greater than for western OR (Table 1), which helps explain the weaker carbon sink there.

The highest NEPs in ecoregions that are not heavily forested were in the agricultural zones of the Willamette
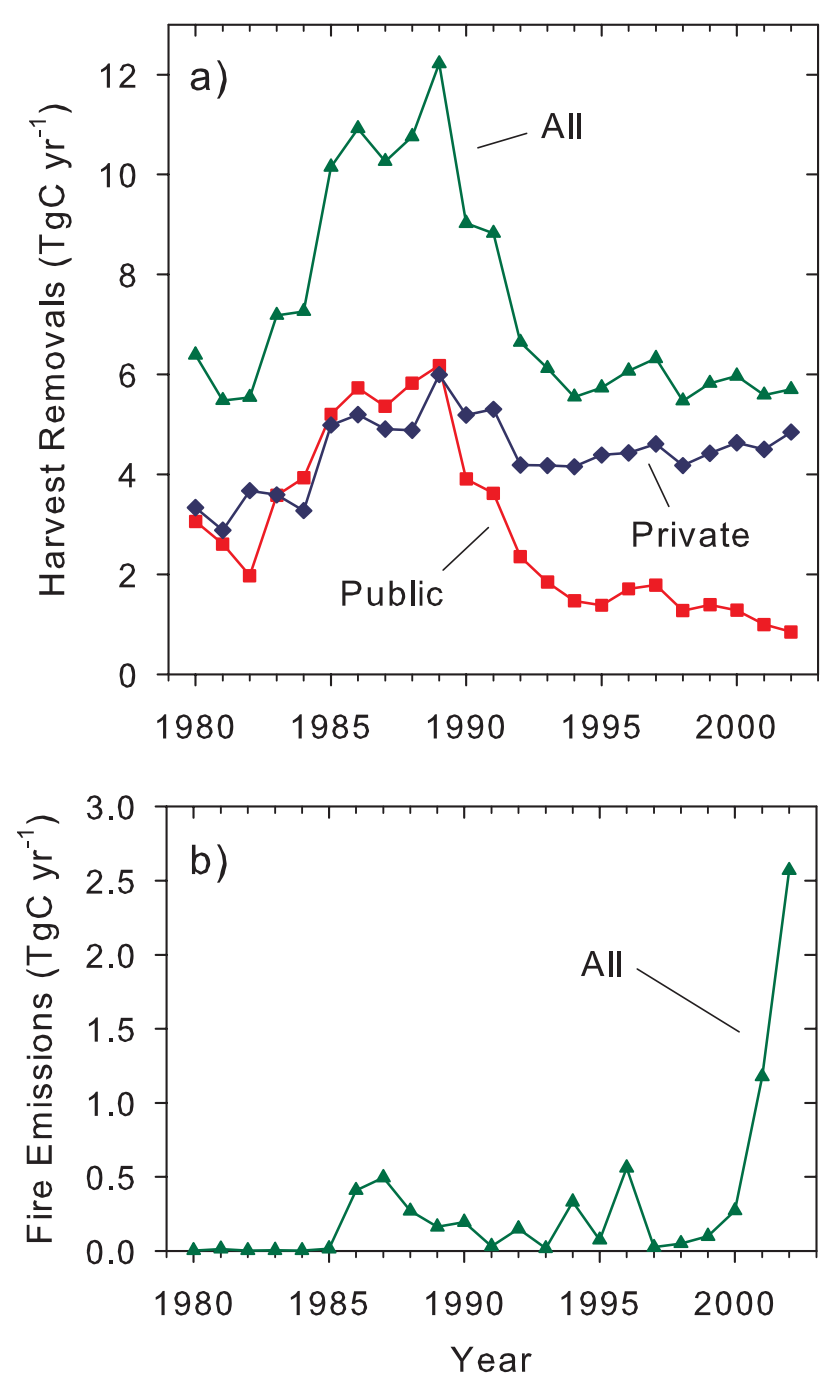

Fig. 4. State-wide (a) timber harvest removals and (b) direct fire emissions by ownership 1980-2002.

Valley and Columbia Plateau ecoregions (Fig. 4, Table 5). There, large areas are planted with highly productive grass or winter wheat, thus generating a high NPP. The heterotrophic respiration in cropland areas is generally much less than NPP (Table 6) because much of the biomass is removed and only residues are plowed back into the soil to decompose (Anthoni et al., 2004; Moureaux et al., 2006).

The large area of Juniper woodlands in eastern OR (Fig. 1) had a low positive mean NEP $\left(41 \pm 56 \mathrm{gC} \mathrm{m}^{-2} \mathrm{yr}^{-1}\right)$ reflecting slow accumulation of bolewood carbon. Earlier studies have highlighted the potential carbon sink from widespread expansion of woodland in the western US over the last century (Houghton et al., 1999). The total woodland NEP for Oregon averaged $0.6 \mathrm{TgC} \mathrm{yr}^{-1}$ over the reference interval.

The NEP for the large area of shrubland in SE Oregon was slightly negative $\left(-10 \pm 46 \mathrm{gC} \mathrm{m}^{-2} \mathrm{yr}^{-1}\right)$ but with 
Table 5. Estimates for net primary production (NPP), heterotrophic respiration $\left(\mathrm{R}_{h}\right)$, net ecosystem production (NEP) by ecoregion. Values are the five-year means and standard deviations for the period 1996-2000.

\begin{tabular}{lcccccc}
\hline Ecoregion & \multicolumn{2}{c}{$\mathrm{NPP}\left(\mathrm{gC} \mathrm{m}^{2} \mathrm{yr}^{-1}\right)$} & \multicolumn{2}{c}{$\mathrm{R}_{h}\left(\mathrm{gC} \mathrm{m}^{2} \mathrm{yr}^{-1}\right)$} & $\mathrm{NEP}\left(\mathrm{gC} \mathrm{m}^{2} \mathrm{yr}^{-1}\right)$ \\
\hline & Mean & $\mathrm{SD}$ & Mean & $\mathrm{SD}$ & Mean & $\mathrm{SD}$ \\
Blue Mountains & 368 & 58 & 347 & 24 & 21 & 37 \\
Cascade Crest & 626 & 25 & 535 & 21 & 91 & 26 \\
Columbia Plateau & 323 & 72 & 283 & 31 & 41 & 54 \\
Coast Range & 814 & 141 & 617 & 40 & 197 & 121 \\
East Cascades & 452 & 43 & 376 & 26 & 76 & 35 \\
Klamath Mountains & 681 & 132 & 566 & 31 & 114 & 109 \\
N. Basin and Range & 187 & 59 & 177 & 21 & 11 & 40 \\
Snake River Plain & 230 & 53 & 193 & 12 & 37 & 45 \\
West Cascades & 840 & 94 & 705 & 33 & 135 & 102 \\
Willamette Valley & 552 & 74 & 406 & 24 & 146 & 61
\end{tabular}

Table 6. Carbon fluxes by cover type. Values are the five year means and standard deviations for the period 1996-2000. NPP = net primary production, $\mathrm{R}_{h}=$ heterotrophic respiration, $\mathrm{NEP}=$ net ecosystem production.

\begin{tabular}{lccccccc}
\hline Cover Type & Area $(\%)$ & \multicolumn{2}{c}{$\mathrm{NPP}\left(\mathrm{gC} \mathrm{m}^{2} \mathrm{yr}^{-1}\right)$} & $\mathrm{R}_{h}\left(\mathrm{gC} \mathrm{m}^{2} \mathrm{yr}^{-1}\right)$ & \multicolumn{2}{c}{$\mathrm{NEP}\left(\mathrm{gC} \mathrm{m}^{2} \mathrm{yr}^{-1}\right)$} \\
\hline Conifer forest & 44 & Mean & $\mathrm{SD}$ & Mean & $\mathrm{SD}$ & Mean & $\mathrm{SD}$ \\
Deciduous forest & 2 & 765 & 91 & 560 & 35 & 105 & 79 \\
Woodland & 7 & 235 & 70 & 194 & 18 & 41 & 56 \\
Shrubland & 32 & 220 & 70 & 229 & 29 & -10 & 46 \\
Grassland & 11 & 425 & 51 & 314 & 15 & 111 & 46 \\
Cropland & 4 & 443 & 51 & 278 & 18 & 166 & 46 \\
\hline
\end{tabular}

interannual variation that included years of positive NEP. The large area of shrubland brought the total for this source to $0.7 \mathrm{TgC} \mathrm{yr}^{-1}$ between 1996 and 2000. This carbon source was the product of a drying trend over the reference period and is consistent with recent eddy flux measurements in a mature sagebrush community in the western U.S. (Obrist et al., 2003).

NBP for the study region was $6.1 \pm 10.2 \mathrm{TgC} \mathrm{yr}^{-1}$ over the 1996-2000 period. Of the ecoregions where NBP was positive, the highest ratio of NBP to NEP was in the Cascade Crest ecoregion (Table 7). This is a high elevation ecoregion where there is little logging or fire. Lower NBP to NEP ratios were found in areas subject to more intensive management. Our simulated timber harvest removals were $5.9 \pm 0.3 \mathrm{TgC} \mathrm{yr}^{-1}$ and were predominantly from the highly productive privately owned forest lands in western Oregon. Harvest removals associated with agricultural lands and grasslands were of a lower magnitude $4.8 \pm 0.3 \mathrm{TgC}^{-1}{ }^{-1}$, but made a significant contribution to the total harvest flux. The contribution of cropland/grassland to NBP was small ($0.3 \mathrm{TgC}^{-1} \mathrm{r}^{-1}$ ) because harvest removals approximately balanced NEP for these lands. Direct carbon emissions from wildfire averaged $0.2 \mathrm{TgC} \mathrm{yr}^{-1}$, which is small relative to forest NEP and harvest removals. Overall, the predominant source of positive NBP was forestland and the high interannual variation in NBP during the reference years was primarily a function of interannual variation in NEP.

The regional total for NBP in Oregon masked a strong difference between the fluxes on public and private forestland. In our analysis, the majority of the forestland NBP for the state was associated with public lands. On private lands, the ratio of growth to removals is close to one (Campbell et al., 2004; Alig et al., 2006), thus tending towards a low NBP. The sharp curtailment of logging on public lands beginning in the early 1990s meant that NBP went from negative to positive on these lands because large quantities of wood were no longer removed from old-growth stands and bolewood production in young stands was left to accumulate. Although volume inventories on public lands in the Pacific Northwest are predicted to continue increasing (Mills and Zhou, 2003; Alig et al., 2006), the carbon sink on these lands is vulnerable to changes in management policy with regard to harvest levels and to fire (Smith and Heath, 2004). Volume inventories on private forest land in the Pacific Northwest are projected to be stable (Alig et al., 2006), consistent with continued intensive management. 
Table 7. Estimates for total net ecosystem production (NEP) and net biome production (NBP) by ecoregion. Values are the five year means and standard deviations for the period 1996-2000.

\begin{tabular}{lccccc}
\hline Ecoregion & Area $\left(\mathrm{km}^{2}\right)$ & \multicolumn{2}{c}{ Total NEP $\left(\mathrm{TgC} \mathrm{yr}^{-1}\right)$} & \multicolumn{2}{c}{ Total NBP $\left(\mathrm{TgC} \mathrm{yr}^{-1}\right)$} \\
\hline & & Mean & $\mathrm{SD}$ & Mean & $\mathrm{SD}$ \\
Blue Mountains & 62424 & 1.3 & 2.3 & -0.9 & 2.2 \\
Cascade Crest & 8175 & 0.8 & 0.2 & 0.6 & 0.2 \\
Columbia Plateau & 17834 & 0.7 & 1.0 & -0.5 & 1.0 \\
Coast Range & 24145 & 4.8 & 2.9 & 2.5 & 2.8 \\
East Cascades & 27958 & 2.1 & 1.0 & 1.3 & 0.9 \\
Klamath Mountains & 15671 & 1.8 & 1.7 & 1.1 & 1.7 \\
Northern Basin and Range & 60116 & 0.7 & 2.4 & 0.2 & 2.3 \\
Snake River Plain & 2634 & 0.1 & 0.1 & 0.0 & 0.1 \\
West Cascades & 20874 & 2.8 & 2.1 & 1.5 & 2.1 \\
Willamette Valley & 13855 & 2.0 & 0.8 & 0.4 & 0.8 \\
Total & & 17.0 & & 6.1 & \\
\hline
\end{tabular}

Although fire suppression has been largely successful in the western U.S., there has recently been an increase in the incidence of wildfire - possibly associated with warming climate (Westerling et al., 2006). Fires are associated not only with direct carbon emissions at the time of burning but also with large post-fire emissions from decomposition of the unburned residual wood. We estimated direct fire emissions in 2002, the year of the 200000 ha Biscuit Fire, at about $3.0 \mathrm{TgC}^{-1}{ }^{-1}$. The post-fire pulse of $\mathrm{R}_{h}$ in the year after

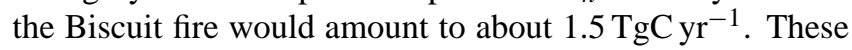
fluxes are significant relative to the statewide carbon sink from NEP.

\subsection{Interannual variation}

Besides masking spatial variation, the regional 5-year mean fluxes also mask significant temporal variation. To isolate the influence of climate on interannual variation in NEP from the influence of disturbance events, we compared the temporal pattern in mean NEP for all areas that were not disturbed with mean NEP for the whole area. The influence of climate dominated the year-to-year changes in NEP (Fig. 5). Interannual variation in NEP over 23 years for all undisturbed grid cells was high (mean of $80 \pm 58 \mathrm{gC} \mathrm{m}^{-2} \mathrm{yr}^{-1}$ ) ranging from $172 \mathrm{gC} \mathrm{m}^{-2} \mathrm{yr}^{-1}$ in 1993 to $-6 \mathrm{gC} \mathrm{m}^{-2} \mathrm{yr}^{-1}$ in 2002 (Fig. 5). Variation in both NPP and $\mathrm{R}_{h}$ contributed to the climatically driven NEP variation, but there was greater dynamic range in NPP $\left(435 \pm 76 \mathrm{gC} \mathrm{m}^{-2} \mathrm{yr}^{-1}\right)$ compared with $\mathrm{R}_{h}\left(355 \pm 22 \mathrm{gC} \mathrm{m}^{-2} \mathrm{yr}^{-1}\right)$. Thus NPP was usually the dominant factor determining the sign of year-to-year changes in NEP, similar to what has been found in simulations with the CASA model over the conterminous U.S. (Potter et al., 2006). Observations at a widely dispersed set of eddy covariance towers in Europe found interannual variation in NEP more strongly related to variation in gross primary production than to variation in ecosystem respiration (Reichstein et

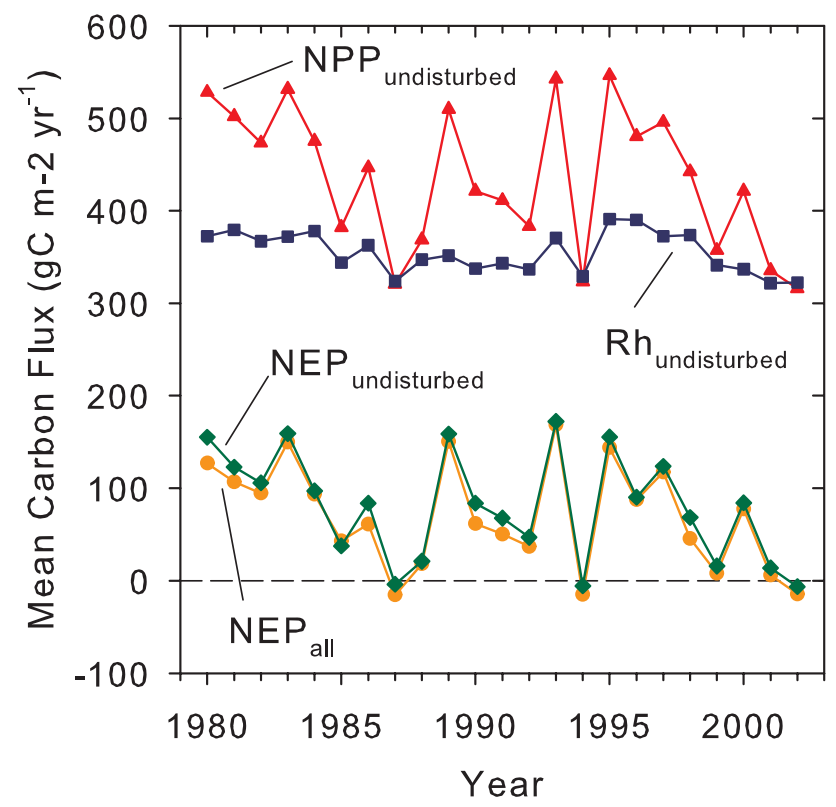

Fig. 5. Interannual variation in state-wide mean net primary production (NPP), heterotrophic respiration $\left(\mathrm{R}_{h}\right)$, and net ecosystem production (NEP) over the interval of 1980 to 2002 for all undisturbed grid cells in Oregon. Mean NEP for all land area is also shown.

al., 2007), also supporting a dominant influence of carbon assimilation on interannual variation in NEP.

Interannual variation in simulated NPP was more strongly correlated with interannual variation in annual precipitation $(R=0.60)$ than with interannual variation in temperature $(R=-0.3)$. NPP and NEP in the PNW region may be particularly sensitive to spring and summer precipitation. Soil moisture is typically (though not always) fully recharged each winter, then is drawn down by increasing evapotranspiration 


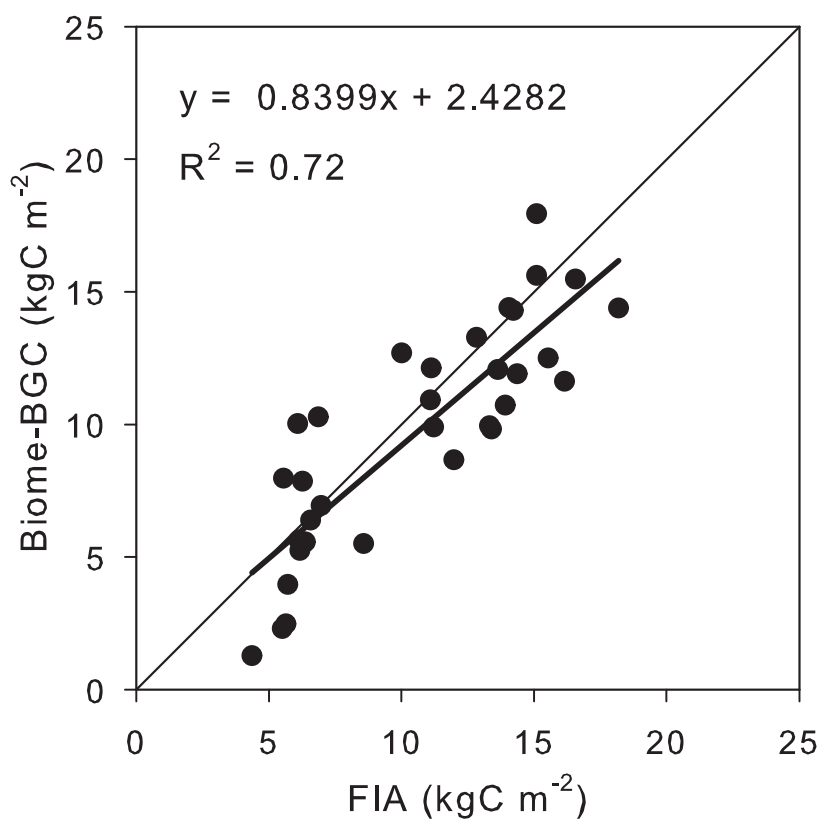

Fig. 6. Comparison of forest inventory (Hicke et al., 2007) and Biome-BGC for mean biomass on forested areas at the county level.

and declining precipitation during spring and early summer. Observations at eddy covariance flux towers in the region find there is a transition from carbon sink to carbon source ( $24 \mathrm{~h}$ sum) that occurs in mid summer (Chen et al., 2004; Law et al., 2000). In years of low NEP, that transition point is pushed earlier in the summer in association with soil drought or high VPD, a pattern also observed in our simulations. Because uncertainty about the magnitude of simulated interannual variation in NEP is relatively high (e.g. Reichstein et al., 2007), it is important that observations at eddy covariance towers - which permit examination of the associated mechanisms - be conducted over multiple years.

High NEP years in our simulations were associated with relatively cool, wet summers such as 1993. In those years, simulated NPP increased markedly because of fewer constraints in mid to late summer on photosynthesis from dry soil and days with high VPD. Field studies on effects of interannual climate variation on forest NPP in our region indicate increased growth in years with cool, wet summers (Peterson and Heath, 1991) and decreased growth associated with dry summers (Kuenierczyk and Ettl, 2002).

Projections of climate change in the Pacific Northwest remain highly uncertain, but recent scenarios from regional climate models suggest warmer temperatures and summer drying over much of the state (Bell and Sloan, 2006; Diffenbaugh et al., 2003; Leung et al., 2004). Based on the sensitivity of our simulated NEPs to years with those characteristics, our results suggest a positive carbon cycle feedback (lower NEP) to projected climatic change over this heterogeneous study area. Extreme drought in Europe during 2003 was associated with reduction in measured NEP for a variety of ecosystems (Ciais et al., 2005; Reichstein et al., 2006), also supporting the suggestion that relatively warm, dry summers could lead to NEP decreases over large areas in some regions. In the Pacific Northwest, the positive feedback mediated by NEP would likely be exacerbated by increased fire emissions (Westerling et al., 2006).

\subsection{Uncertainty assessment}

In the comparisons of mean forest biomass at the county level, there was generally good agreement across all counties (Fig. 6) suggesting no overall strong bias in our biomass estimates. The overall weighted mean biomass was $12.5 \mathrm{kgC} \mathrm{m}^{-2}$ from the inventory data and $11.7 \mathrm{kgC} \mathrm{m}^{-2}$ for the BGC simulations. The area of greatest uncertainty with regard to our forestland carbon stocks is in the eastern part of the state where carbon stock estimates from Biome-BGC are sensitive to the assumed age for all stands $>30$ years of age. Alterative means of mapping stand age and stand structure based on remote sensing are under development (Ohmann and Gregory, 2002; Hurtt et al., 2004; Lefsky et al., 2005) and offer prospects for improving estimates of biomass in these areas.

Carbon stocks for nonforest cover types are less well constrained. For juniper woodland, our mean tree biomass $\left(1.5 \mathrm{kgC} \mathrm{m}^{-2}\right)$ was close to that approximated from a recent inventory (Azuma et al., 2005). Mean shrubland biomass $\left(0.6 \mathrm{kgC} \mathrm{m}^{-2}\right)$ was also in the range of observations from the one available study in our region (Sapsis and Kaufmann, 1991). Cropland and grassland biomass carbon is discussed below in relation to NPP estimates.

For the estimate of carbon flux from forest inventory data, Smith et al. (2004) report the total wood volume for timberland in 1987 and in 1997 in Oregon and the difference between them in terms of carbon divided by the interval is a 7.2 $\mathrm{TgC} \mathrm{yr}^{-1}$ gain in tree carbon. That estimate did not include changes in carbon stocks on reserved lands (10\% of total timberland). A state-level analysis (Campbell et al., 2004) reports the difference between gross growth and the sum of mortality plus harvest removals at $2.2 \mathrm{TgC} \mathrm{yr}^{-1}$ for 1999 on unreserved timberland. If reserved timberland were assumed to sequester $150 \mathrm{gC} \mathrm{m}^{-2} \mathrm{yr}^{-1}$, that would bring their total to $2.8 \mathrm{TgC} \mathrm{yr}^{-1}$. Our estimate for forestland NBP in the late $1990 \mathrm{~s}$ is $\sim 6 \mathrm{TgC} \mathrm{yr}^{-1}$. As far as the distribution of the carbon sink among ecoregions and ownerships, our results agree with inventory based reports that suggest large gains of tree carbon on public lands in Oregon (Alig et al., 2006; Smith and Heath, 2004), and losses on private forestland in eastern Oregon (Azuma et al., 2004).

Another important term in the forestland carbon budget that can be checked independently is the tree harvest removals. Our simulated removals for the 1996-2000 period were $5.9 \pm 0.3 \mathrm{TgC} \mathrm{yr}^{-1}$, which compares closely with the data from the Oregon Department of Forestry 
$\left(6.1 \pm 0.3 \mathrm{TgC}^{-1}\right)$. The other process by which carbon is lost directly from the land base is fire emissions. We have no direct check on our emissions estimates except for the Biscuit Fire and there a detailed analysis by Campbell et al. (2007) gave $3.2 \mathrm{TgC}$ source for the portion of the burned area in Oregon compared to our simulated value of $2.9 \mathrm{TgC}$. Our estimates are most likely underestimates because our change detection analysis identifies only stand replacing fires, thus omitting significant areas that are partially burned or have understory fires.

The positive NEP on forestland in our analysis showed up largely in the form of tree biomass. We did not find conspicuous trends in regional mean carbon storage in forest soils or litter. There have been several large scale analyses of forest soil carbon pools in the Pacific Northwest region (Homann et al., 1998; Kern et al., 1998) but they have not addressed possible changes over time. The measurement error of the soil carbon pool is generally large relative to the kinds of yearto-year changes that might be expected due to management or climate variability. The pool of CWD in our analysis varied significantly from year to year depending on the level of disturbance. USDA Forest Service inventory surveys are beginning to measure CWD mass (Chojnacky and Heath, 2002) but there is not as yet enough data to indicate trends.

Our cropland NPP values were generally lower than the mean NPPs derived from the (USDA, 2001) data (17\% lower across all ecoregions). This may in part reflect the effects of irrigation and fertilization, factors that are not treated in our simulations. Our summed crop harvest removals averaged $1.7 \pm 0.2 \mathrm{TgC} \mathrm{yr}^{-1}$, which is slightly higher than the comparable NASS estimates for Oregon $\left(1.6 \pm 0.3 \mathrm{TgC} \mathrm{yr}^{-1}\right)$ because it is associated with a larger area $\left(9572 \mathrm{~km}^{2}\right.$ vs. $8823 \mathrm{~km}^{2}$ ). Our harvest removals from grasslands were $3.0 \pm 0.2 \mathrm{TgC} \mathrm{yr}^{-1}$. Mean NBP on cropland/grassland was $-0.2 \mathrm{TgC} \mathrm{yr}^{-1}$, consistent with an approximate balance of NEP and harvest removals. Cropland soils in Oregon have been estimated to sequester $0.2 \mathrm{TgC} \mathrm{yr}^{-1}$ (EPA, 2006), close to the near steady state in our analysis. Most croplands in the study region have been in production for many decades, thus have already been through the typical draw down of soil carbon stocks associated with newly converted fields.

For the purposes of comparing our NEP estimates with terrestrial carbon flux (excluding fire emissions) from the Carbon Tracker (CT) inversion scheme (NOAA 2007), we resampled the $\mathrm{CT}$ annual sums for the optimized surface flux from $1^{\circ} \times 1^{\circ}$ to $1 \mathrm{~km}$, and determined the state-wide mean. That mean for 2000 (the first year of CT outputs) was $71 \mathrm{gC} \mathrm{m}^{-2} \mathrm{yr}^{-1}$ for CT which compares with $78 \mathrm{gC} \mathrm{m}^{-2} \mathrm{yr}^{-1}$ for mean NEP from our Biome-BGC simulations. The two surfaces agreed in having higher values in the more mesic western part of the state, but the highest CT values were in the vicinity of agricultural areas whereas in our simulations they were in forested areas. Both approaches showed decreases in 2001 and 2002 (drier years than 2000), but the CT decreases were not as strong as in our simula- tions. There were few $\mathrm{CO}_{2}$ measurement stations for $\mathrm{CT}$ in the vicinity of Oregon, so these inversion fluxes were not greatly constrained by the measurements; but this first order comparison of bottom-up and top-down terrestrial fluxes at the regional scale indicates the great potential of these comparisons for identifying areas of greatest uncertainty.

\subsection{Offsets to fossil fuel emissions}

Our state-level budget indicates that much of the carbon sequestered by NEP in Oregon is removed from the land base. In terms of offsetting $\mathrm{CO}_{2}$ emissions, the crop/grass removals would return to the atmosphere relatively rapidly so should make no contribution to offsets. In the case of forest products, however, there is a significant proportion that has a long turnover time, and these products can contribute to national-level carbon sinks in the development of national greenhouse gas emissions inventories under FCCC accounting (EPA, 2006). In the Pacific Northwest, the disequilibrium between harvest emissions from all previous harvests and total current harvests has been approximated at 25\% (Harmon et al., 1996) thus forest products can be estimated to contribute a carbon sink of $\sim 1.4 \mathrm{TgC} \mathrm{yr}^{-1}$.

The 5-year (1996-2000) mean fossil fuel carbon source was $15.0 \mathrm{TgC} \mathrm{yr}^{-1}$ for the state of Oregon (ODE, 2003), a value of comparable magnitude to the mean NEP flux. As noted, however, for carbon accounting purposes (EPA, 2006) it is really the sum of NBP and the net product sink (total of 7.6 $\mathrm{TgC}^{-1}{ }^{-1}$ ) which should be compared to fossil fuel emissions. In that case, $51 \%$ of the fossil fuel emissions are balanced by carbon sequestration. Oregon has a relatively high area of forestland and low population density, which helps explain the large fossil fuel offset. At the national level, the forest sector has been estimated to balance $10-20 \%$ of U.S. fossil fuel emissions (Turner et al., 1995, Houghton et al., 1999). For the European Union, the comparable estimate is $7-12 \%$ (Janssens et al., 2003).

\subsection{Limitations and future directions}

A notable limitation of the approach here is that land cover is held constant over the duration of the simulation. This assumption is justified for the most part in Oregon because rates of land use and land cover change are quite low in recent years (Alig and Butler, 2004). However, as the Landsat record is extended in time, and as this type of modeling approach is applied in other regions, it would be desirable to introduce land cover change as a type of disturbance. This could be readily included in the Biome-BGC modeling framework. One case in which land cover change in Oregon would be of interest is regarding the expansion of juniper woodland. Woodland expansion has been on-going in Oregon over the last century (Azuma et al., 2005) but the carbon consequences are not well understood. 


\section{Appendix}

Table A1. Cover-type-specific parameters for Biome-BGC. Values were modified at the ecoregion scale where local information was available (e.g. Table 3).

\begin{tabular}{|c|c|c|c|c|c|c|c|}
\hline Parameter & Unit & ENF & DBF & WDL & SBL & GSL & CRP \\
\hline \multicolumn{8}{|l|}{ Annual turnover rates } \\
\hline Leaves and fine roots & Year $^{-1}$ & 0.167 & 1 & 0.25 & 0.25 & 1 & 1 \\
\hline Live wood & Year $^{-1}$ & 0.7 & 0.7 & 0.7 & 0.7 & NA & NA \\
\hline Whole plant mortality & Year $^{-1}$ & 0.01 & 0.02 & 0.02 & 0.05 & NA & NA \\
\hline Fire mortality & Year $^{-1}$ & 0 & 0 & 0 & 0 & 0 & 0 \\
\hline \multicolumn{8}{|l|}{ Allocation ratios } \\
\hline Fine $\operatorname{root} \mathrm{C} /$ leaf $\mathrm{C}$ & DIM & 1.3 & 1 & 2.5 & 1 & 2 & 1 \\
\hline Stem C/leaf C & DIM & 2.2 & 2.2 & 2 & 0.22 & NA & NA \\
\hline Live wood C/total wood C & DIM & 0.071 & 0.1 & 0.2 & 1 & NA & NA \\
\hline Coarse Root C/Stem C & DIM & 0.25 & 0.23 & 0.24 & 0.3 & NA & NA \\
\hline Growth C/storage C & DIM & 0.5 & 0.5 & 0.5 & 0.5 & 0.5 & 0.5 \\
\hline \multicolumn{8}{|l|}{$\mathrm{C} / \mathrm{N}$ ratios } \\
\hline $\mathrm{C} / \mathrm{N}$ of leaves & DIM & 52 & 35 & 52 & 42 & 24 & 24 \\
\hline $\mathrm{C} / \mathrm{N}$ of falling leaf litter & DIM & 93 & 55 & 93 & 93 & 49 & 49 \\
\hline $\mathrm{C} / \mathrm{N}$ of fine roots & DIM & 75 & 48 & 90 & 42 & 42 & 42 \\
\hline $\mathrm{C} / \mathrm{N}$ of live wood & DIM & 50 & 50 & 50 & 50 & NA & NA \\
\hline $\mathrm{C} / \mathrm{N}$ of dead wood & DIM & 729 & 550 & 729 & 729 & NA & NA \\
\hline \multicolumn{8}{|l|}{ Leaf litter proportions } \\
\hline Labile proportion & DIM & 0.32 & 0.39 & 0.32 & 0.32 & 0.39 & 0.39 \\
\hline Cellulose proportion & DIM & 0.44 & 0.44 & 0.44 & 0.44 & 0.44 & 0.44 \\
\hline Lignin proportion & DIM & 0.24 & 0.17 & 0.24 & 0.24 & 0.17 & 0.17 \\
\hline \multicolumn{8}{|l|}{ Fine roots proportions } \\
\hline Fine root labile proportion & DIM & 0.3 & 0.3 & 0.3 & 0.3 & 0.3 & 0.3 \\
\hline Fine root cellulose proportion & DIM & 0.45 & 0.45 & 0.45 & 0.45 & 0.45 & 0.45 \\
\hline Fine root lignin proportion & DIM & 0.25 & 0.25 & 0.25 & 0.25 & 0.25 & 0.25 \\
\hline \multicolumn{8}{|l|}{ Dead wood proportions } \\
\hline Cellulose proportion & DIM & 0.71 & 0.76 & 0.76 & 0.76 & NA & NA \\
\hline Lignin proportion & DIM & 0.29 & 0.24 & 0.24 & 0.24 & NA & NA \\
\hline \multicolumn{8}{|l|}{ Canopy parameters } \\
\hline Water interception coefficient & $\mathrm{LAI}^{-1} \mathrm{~d}^{-1}$ & 0.05 & 0.041 & 0.041 & 0.041 & 0.021 & 0.021 \\
\hline Light extinction coefficient & DIM & 0.5 & 0.54 & 0.5 & 0.5 & 0.6 & 0.48 \\
\hline Average specific leaf area & $\mathrm{m}^{2} \mathrm{kgC}^{-1}$ & 10 & 32 & 7.7 & 12 & 32 & 32 \\
\hline Ratio of sunlit to shaded LAI & DIM & 2 & 2 & 1 & 2 & 2 & 2 \\
\hline Ratio of all sided to projected LAI & DIM & 2.6 & 2.0 & 2.9 & 2.6 & 2.0 & 2.0 \\
\hline Fraction of leaf $\mathrm{N}$ in Rubisco & DIM & 0.06 & 0.08 & 0.05 & 0.06 & 0.20 & 0.25 \\
\hline \multicolumn{8}{|l|}{ Conductance parameters } \\
\hline Maximum stomatal conductance & $\mathrm{m} \mathrm{s}^{-1}$ & 0.0015 & 0.003 & 0.002 & 0.003 & 0.005 & 0.005 \\
\hline Cuticular conductance & $\mathrm{m} \mathrm{s}^{-1}$ & 0.00002 & 0.00003 & 0.00001 & 0.00003 & 0.00005 & 0.00005 \\
\hline Boundary layer conductance & $\mathrm{m} \mathrm{s}^{-1}$ & 0.09 & 0.01 & 0.08 & 0.08 & 0.04 & 0.04 \\
\hline \multicolumn{8}{|l|}{ Boundaries for conduction reduction } \\
\hline Leaf water potential: start of reduction & $\mathrm{MPa}$ & -0.5 & -0.7 & -0.7 & -0.6 & -0.6 & -0.6 \\
\hline Leaf water potential: complete reduction & $\mathrm{MPa}$ & -2.3 & -2.5 & -2.5 & -2.3 & -2.3 & -2.3 \\
\hline VPD: start of reduction & $\mathrm{Pa}$ & 600 & 1100 & 1000 & 930 & 930 & 930 \\
\hline VPD: complete reduction & $\mathrm{Pa}$ & 2250 & 3600 & 5000 & 4100 & 4100 & 4100 \\
\hline
\end{tabular}

$\mathrm{ENF}=$ evergreen needleleaf forest, $\mathrm{DBF}=$ deciduous broadleaf forest, $\mathrm{WDL}=$ woodland, $\mathrm{SBL}=$ shrubland, $\mathrm{GSL}=\mathrm{grassland}, \mathrm{CRP}=\mathrm{cropland}$. $\mathrm{NA}=$ Not applicable, DIM = dimensionless. 
A second limitation of our approach is in neglecting management interventions such as thinning. In recent years thinning has become an increasingly important tool in regional forest management, particularly as an approach to reducing fuel loads and the risk of fire (Brown et al., 2004). Thinning is potentially detectable with remote sensing (Healey et al., 2006), and Biome-BGC could be adapted to simulate the consequences in terms of carbon pools and flux (Ceinciala and Tatarinov, 2006). Thus, there are reasonable prospects for including its effect in future regional carbon budgets.

In additional to direct management activities, there are several indirect influences on ecosystem level carbon budgets that could also be considered. We included the effect of increasing $\mathrm{CO}_{2}$ concentration up to the present, as in Thornton et al. (2002). Although Thornton et al. (2002) concluded that direct $\mathrm{CO}_{2}$ effects are currently not a big influence on NEP relative to disturbance effects, a continuing increase could be expected to maintain a disequilibrium in carbon inputs and outputs, favoring a carbon sink when disturbance is not a factor, e.g. as in boreal forests (Lagergren et al., 2006). We did not model effects of nitrogen deposition, which would be expected to increase carbon sinks, nor did we treat effects of tropospheric ozone, which would be expected to decrease carbon sinks. Neither of these factors appears to be important as yet in Oregon, but process models such as Biome-BGC can be used to account for them and this provides a strong rationale for the distributed modeling approach to formulating regional carbon budgets.

\section{Conclusions}

Our results support the general conclusion that land management is a dominant control on the terrestrial carbon balance in temperate regions. In Oregon, the NBP on forestland is strongly dependent on land ownership since intensive management on privately owned forestland tends to keep NEP balanced by harvest removals whereas biomass is accumulating on public lands where harvest levels are low. Juniper woodlands contribute about $10 \%$ to the state-level carbon sequestration. NBP on non-forest lands is close to zero: on croplands and grasslands because removals balance NEP, and on shrublands because NEP swings between positive and negative depending on the climate year. The spatial and temporal heterogeneity in NEP introduced by environmental gradients, by land use, and by interannual variation in climate are of similar magnitude, thus they should all be simulated in efforts to understand regional carbon budgets and to interpret carbon fluxes inferred from $\mathrm{CO}_{2}$ mixing ratio observations.

Acknowledgements. This research was supported by the U.S. Department of Energy Biological and Environmental Research Terrestrial Carbon Program (Award \# DE-FG02-04ER63917). Special thanks to Peter Thornton for generating and providing the DAYMET climate data. CarbonTracker results provided by NOAA/OAR/ESRL GMD, Boulder, Colorado, USA.
Edited by: J. Kesselmeier

\section{References}

Acker, S. A., Halpern, C. B., Harmon, M. E., and Dyrness, C. T.: Trends in bole biomass accumulation, net primary production and tree mortality in Psuedotsuga menziesii forest of contrasting age, Tree Physiol., 22, 213-217, 2002.

Alerich, C. L., Klevgard, L., Liff, C., and Miles, P. D.: The Forest Inventory and Analysis Database: Database Description and Users Guide Version 1.7, USDA Forest Service, North Central Research Station, NC-218, 193 pp., 2004.

Alig, R. and Butler, B.: Forest cover changes in the United States: 1952-1997, with projections to 2050, USDA Forest Service, Portland Oregon, PNW-GTR-613, 106 pp., 2004.

Alig, R. J., Krankina, O. N., Yost, A., and Kuzminykh, J.: Forest carbon dynamics in the Pacific Northwest (USA) and the St. Petersburg region of Russia: Comparisons and policy implications, Clim. Change, 79, 335-360, 2006.

Anthoni, P. M., Freibauer, A., Kolle, O., and Schultze, E.-D.: Winter wheat exchange in Thuringia, Germany, Agr. Forest Meteorol., 121, 55-67, 2004.

Azuma, D. L., Dunham, P. A., and Veneklase, B. A.: Timber Resource Statistics of Eastern Oregon, 1999, Resource Bulletin PNW-RB-238, USDA Forest Service, PNW Research Station, Portland OR, 42 pp. 2004.

Azuma, D. L., Hiserote, B., and Dunham, P. A.: The Western Juniper Resource of Eastern Oregon, U.S. Department of Agriculture, Pacific Northwest Research Station, PNW-RB-249, 18 pp., 2005.

Bachelet, D., Neilson, R. P., Lenihan, J. M., and Drapek, R. J.: Climate change effects on vegetation distribution and carbon budget in the United States, Ecosystems, 4, 164-185, 2001.

Baker, D. F., Law, R. M., Gurney, K. R., Rayner, P., Peylin, P., Denning, A. S., Bousquet, P., Bruhwiler, L., Chen, Y. H., Ciais, P., Fung, I. Y., Heimann, M., John, J., Maki, T., Maksyutov, S., Masarie, K., Prather, M., Pak, B., Taguchi, S., and Zhu, Z.: TransCom 3 inversion intercomparison: Impact of transport model errors on the interannual variability of regional $\mathrm{CO}_{2}$ fluxes, 1988-2003, Global Biogeochem. Cy., 20, GB1002, doi:10.1029/2004GB002439, 2006, 2006.

Bell, J. L. and Sloan, L. C.: $\mathrm{CO}_{2}$ sensitivity of extreme climate events in the western United States, Earth Interact., 10, Paper 15, 1-17, 2006.

Bousquet, P., Peylin, P., Ciais, P., Quere, C. L., Friedlingstein, P., and Tans, P. P.: Regional changes in carbon dioxide fluxes of land and oceans since 1980, Science, 290, 1342-1346, 2000.

Brown, R. T., Agee, J. K., and Franklin, J. F.: Forest restoration and fire: principles in the context of place, Conserv. Biol., 18, 903-912, 2004.

Campbell, J. L., Sun, O. J., and Law, B. E.: Disturbance and net ecosystem production across three climatically distinct forest landscapes, Global Biogeochem. Cy., 18, GB4017, doi:10.1029/2004GB002236, 2004.

Campbell, J. L., Law, B. E., and Donato, D.: Carbon emissions from the Biscuit Fire, J.Geophys. Res.-Bio., in press, 2007.

Campbell, S., Azuma, D. L., and Weyermann, D.: Forests of Western Oregon: an Overview, USDA Forest Service, PNW Station, 
Portland, OR, General Technical Report, PNW-GTR-525, 27 pp., 2002.

Ceinciala, E. and Tatarinov, F. A.: Application of BIOME-BGC model to managed forests. 2. Comparison with long-term observations of stand production for major tree species, Forest Ecol. Manage., 237, 252-266, 2006.

Chen, J. M., Paw U, K. T., Ustin, S. L., Suchanek, T. H., Bond, B. J., Brosofske, K. D., and Falk, M.: Net ecosystem exchanges of carbon, water, and energy in young and old-growth Douglas-fir forests, Ecosystems, 7, 534-544, 2004.

Chojnacky, D. C. and Heath, L. S.: Estimating down deadwood from FIA forest inventory variables in Maine, Environ. Pollut., 116, 243-248, 2002.

Cohen, W. B., Harmon, M. E., Wallin, D. O., and Fiorella, M.: Two decades of carbon flux from forests of the Pacific Northwest, BioScience, 46, 836-844, 1996.

Cohen, W. B., Spies, T. A., Alig, R. J., Oetter, D. R., Maiersperger, T. K., and Fiorella, M.: Characterizing 23 years (1972-95) of stand replacement disturbance in western Oregon forests with Landsat imagery, Ecosystems, 5, 122-137, 2002.

Cohen, W. B., Spies, T. A., and Fiorella, M.: Estimating the age and structure of forests in a multi-ownership landscape of western Oregon, USA, Int. J. Remote Sens., 16, 721-746, 1995.

CONUS: Conterminous United States multi-layer soil characteristics data set for regional climate and hydrology modeling, http: //www.soilinfo.psu.edu/index.cgi?soil_data \\&conus, 2007.

DAYMET: Distributed climate data, http://www.daymet.org/, 2006.

DeBell, D. S. and Franklin, J. F.: Old-growth Douglas-fir and western hemlock: a 36-year record of growth and mortality, West. J. Appl. For., 2, 111-114, 1987.

Diffenbaugh, N. S., Sloan, L. C., Snyder, M. A., Bell, J. L., Kaplan, J., Shafer, S. L., and Bartlein, P. J.: Vegetation sensitivity to global anthropogenic carbon dioxide emissions in a topographically complex region, Global Biogeochem. Cy., 17, 1067, doi:10.1029/2002/GB001974, 2003.

EPA: Inventory of U.S. Greenhouse Gas Emissions and Sinks:1990-2004, USEPA \#430-R-06-002, http://www.epa. gov/climatechange/emissions/usinventoryreport.htm, 2006.

FIA: U.S. Department of Agriculture Forest Inventory and Analysis Program, http://fia.fs.fed.us, 2006.

Garman, S. L., Swanson, F. J., and Spies, T. A.: Past, present, future landscape patterns in the Douglas-fir region of the Pacific Northwest, in: Forest Fragmentation: Wildlife and Management Implications, edited by: Rochelle, J. A., Lehmann, L. A., and Wisniewski, J., Brill Academic Publishing, The Netherlands, 61-86, 1999.

Gedney, D. R., Azuma, D. L., Bolsinger, C. L., and McKay, N.: Western Juniper in Eastern Oregon, PNW-GTR-464, U.S. Department of Agriculture, Forest Service Pacific Northwest Research Station, Portland, OR, 53 pp., 1999.

Gholz, H. L.: Environmental limits on above ground net primary production, leaf area, and biomass in vegetation zones of the $\mathrm{Pa}$ cific Northwest, Ecology, 63, 469-481, 1982.

Harmon, M. E., Harmon, J. M., Ferrell, W. K., and Brooks, D.: Modeling carbon stores in Oregon and Washington forest products: 1900-1992, Climatic Change, 33, 521-550, 1996.

Hasenauer, H., Merganicova, K., Petritsch, R., Pietsch, S. A., and Thornton, P. E.: Validating daily climate interpolations over complex terrain in Austria, Agric. Forest Meteorol., 119, 87-107,
2003.

Healey, S. P., Cohen, W. B., Yang, Z., and Krankina, O. N.: Comparison of Tasseled Cap-based Landsat data structures for use in forest disturbance detection, Rem. Sens. Environ., 97, 301-310, 2005.

Healey, S. P., Yang, Z., Cohen, W. B., and Pierce, D. J.: Application of two regression-based methods to estimate the effects of partial harvest on forest structure using Landsat data, Rem. Sens. Environ., 101, 115-126, 2006.

Hicke, J. A., Jenkins, J. C., Ojima, D. S., and Ducey, M.: Spatial patterns of forest characteristics in the western United States derived from inventories, Ecol. Appl., in press, 2007.

Homann, P. S., Sollins, P., Fiorella, M., Thorson, T., and Kern, J. S.: Regional soil organic carbon storage estimates for western Oregon by multiple approaches, Soil Sci. Soc. Am. J., 62, 789796, 1998.

Houghton, R. A., Hackler, J. L., and Lawrence, K. T.: The U.S. carbon budget: contribution from land use change, Science, 285, 574-578, 1999.

Hurtt, G. C., Dubayah, R., Drake, J., Moorcraft, P. R., Pacala, S. W., Balir, J. B., and Fearon, M. G.: Beyond potential vegetation: combining lidar data and a height-structured model for carbon studies, Ecol. Appl., 14, 873-883, 2004.

Janssens, I. A., Freibauer, A., Ciais, P., Smith, P., Nabuurs, G.J., Folberth, G., Schlamadinger, B., Hutjes, R. W. A., Ceulemans, R., Schulze, E.-D., Valentini, R., and Dolman, A. J.: Europe's terrestrial biosphere absorbs 7 to $12 \%$ of European anthropogenic $\mathrm{CO}_{2}$ emissions, Science, 300, 1538-1542, 2003.

Kagan, J. S., Hak, J. C., Csuti, B., Kiilsgaurd, C. W., and Gaines, E. P.: Oregon Gap Analysis Project Final Report: A geographic approach to planning for biological diversity, 1999.

Karstens, U., Gloor, M., Heimann, M., and Rodenbeck, C.: Insights from simulations with high-resolution transport and process models on sampling of the atmosphere for constraining midlatitude land carbon sinks, J. Geophys. Res.-Atmos., 111, D12301, doi:10.1029/2005JD006278, 2006.

Kauppi, P. E., Mielikainen, K., and Kuusela, K.: Biomass and carbon budget of European forests, 1971-1990, Science, 256, 7074, 1992.

Kern, J. S., Turner, D. P., and Dodson, R. F.: Spatial patterns in soil organic carbon pool size in the Northwestern United States, in: Soil Processes and the Carbon Cycle, edited by: Lal, R., Kimbal, J. M., Follett, R., and Stewart, B. A., CRC Press, Boca Raton, FL, 29-43, 1998.

Korner, C.: Slow in, rapid out - carbon flux studies and Kyoto targets, Science, 300, 1242-1243, 2003.

Lagergren, F., Grelle, A., Lankreijer, H., Molder, M., and Lindroth, A.: Current carbon balance of the forested area in Sweden and its sensitivity to global change as simulated by Biome-BGC, Ecosystems, 9, 894-908, 2006.

Law, B. E., Turner, D., Campbell, J., Van Tuyl, S., Ritts, W. D., and Cohen, W. B.: Disturbance and climate effects on carbon stocks and fluxes across Western Oregon USA, Global Change Biol., 10, 1429-1444, 2004.

Law, B. E., Turner, D. P., Lefsky, M., Campbell, J., Guzy, M., Sun, O., VanTuyl, S., and Cohen, W. B.: Carbon fluxes across regions: observational constraints at multiple scales, in: Scaling and Uncertainity Analysis in Ecology: Methods and Applications, edited by: Wu, J., Jones, K. B., Li, H., Loucks, O. L., 
Columbia University Press, New York, 167-190, 2006.

Law, B. E., Waring, R. H., Anthoni, P. M., and Aber, J. D.: Measurements of gross and net ecosystem productivity and water vapor exchange of a Pinus ponderosa ecosystem, and an evaluation of two generalized models, Global Change Biol., 6, 155-168, 2000.

Lefsky, M. A., Harding, D. J., Keller, M., Cohen, W. B., Carabajal, C. C., Espirito-Santo, F. D. B., Hunter, M. O., and de Oliveira, R.: Estimates of forest canopy height and aboveground biomass using ICESat, Geophys. Res. Lett., 32, L22S02, doi:10.1029/2005GL023971, 2005, 2005.

Lennartz, S.: Oregon Forest Land Change Mapping, Sanborn Mapping Solutions, Portland, OR, 2005.

Leung, L. R., Qian, Y., and Bian, X.: Midcentury ensemble regional climate change scenarios for the western United States, Clim. Change, 62, 75-113, 2004.

Loveland, T. R. and Merchant, J. M.: Ecoregions and ecoregionalization: geographical and ecological perspectives, Environ. Manage., doi:10.1007/s00267-003-5181-x, 2004.

Lovett, G. M., Cole, L. L., and Pace, M. L.: Is net ecosystem production equal to ecosystem carbon accumulation?, Ecosystems, 9, 152-155, 2006.

Lutz, J. A. and Halpern, C. B.: Tree mortality during early forest development: a long term study of rates, causes, and consequences, Ecol. Monogr., 76, 257-275, 2006.

Miller, D. A. and White, R. A.: A Conterminous United States Multi-Layer Soil Characteristics Data Set for Regional Climate and Hydrology Modeling, Earth Interactions, 2 (available online at http://EarthInteractions.org), 1998.

Mills, J. R. and Zhou, X.: Projecting national forest inventories for the 2000 RPA timber assessment, 58 pp. 2003.

Moeur, M., Spies, T. A., Hemstrom, M., Martin, J. R., Alegria, J., Browning, J., Cissel, J., Cohen, W. B., Demeo, T. E., Healey, S. P., and Warbington, R.: Northwest Forest Plan - The First Ten Years (1994-2003): Status and Trend of Late-Successional and Old-Growth Forests, USDA Forest Service, Pacific Northwest Research Station, Portland OR, PNW-GTR 649, 142 pp., 2005.

Morgenstern, K., Black, T. A., Humphreys, E. R., Griffis, T. J., Drewitt, G. B., Cai, T., Nesic, Z., Spittlehouse, D. L., and Livingston, N. J.: Sensitivity and uncertainty of the carbon balance of a Pacific Northwest Douglas-fir forest during an ElNino/LaNina cycle, Agr. Forest Meteorol., 123, 201-219, 2004.

Mote, P. W.: Trends in temperature and precipitation in the Pacific Northwest during the twentieth century, Northwest Sci., 77, 271282, 2003.

Moureaux, C., Debacq, A., Bodson, B., Heinesch, B., and Aubinet, M.: Annual net ecosystem carbon exchange by a sugar beet crop, Agric. Forest Meteorol., 139, 25-39, 2006.

NOAA: National Oceanic and Atmospheric Administration, http: //www.cmdl.noaa.gov/ccgg/carbontracker, 2007.

NWCC: Northwest Interagency Coordination Center, 2004 Annual Intelligence Report, available at http://www.nwccweb.us/admin/ publications.asp, 2004.

Obrist, D., Delucia, D. H., and Arnone, J. A.: Consequences of wildfire on ecosystem $\mathrm{CO}_{2}$ and water vapour fluxes in the Great Basin, Global Change Biol., 9, 563-574, 2003.

ODE: Report on reducing Oregon's greenhouse gas emissions, Oregon Department of Energy, http://oregon.gov/ENERGY/ GBLWRM/Draft_Intro.shtml, 2003.
ODF: Oregon Department of Forestry, Complete Harvest Data 1962-Present, http://www.odf.state.or.us/DIVISIONS/resource policy/resource_planning/Annual_Reports/, 2006.

Ogle, S. M., Breidt, F. J., and Paustian, K.: Bias and variance in model results associated with spatial scaling of measurements for parameterization in regional assessments, Global Change Biol., 12, 1-8, 2006.

Ohmann, J. L. and Gregory, M. J.: Predictive mapping of forest composition and structure with direct gradient analysis and nearest-neighbor imputation in coastal Oregon, USA, Can. J. For. Res., 32, 725-741, 2002.

Omernik, J. M.: Ecoregions of the conterminous United States. Map (scale 1:7 500 000), Ann. Assoc. Am. Geogr., 77, 118-125, 1987.

Pacala, S. W., Hurtt, G. C., Baker, D., Peylin, P., Houghton, R. A., Birdsey, R. A., Heath, L. S., Sundquist, E. T., Stallard, R. F., Ciais, P., Moorcroft, P., Caspersen, J. P., Shevliakova, E., Moore, B., Kohlmaier, G., Holland, E. A., Gloor, M., Harmon, M. E., Fan, S.-M., Sarmiento, J. L., Goodale, C. L., Schimel, D., and Field, C. B.: Consistent land- and atmosphere-based U.S. carbon sink estimates, Science, 292, 2316-2322, 2001.

Paw U, K. T., Falk, M., Suchanek, T. H., Ustin, S. L., Chen, J., Park, Y., Winner, W. E., Thomas, S. C., Hsiao, T. C., Shwa, R. H., King, T. S., Pyles, R. D., Schroeder, M., and Matista, A. A.: Carbon dioxide exchange between an old-growth forest and the atmosphere, Ecosystems, 7, 513-524, 2004.

Pietsch, S. A. and Hasenauer, H.: Evaluating the self-initialization procedure for large-scale ecosystem models, Global Change Biol., 12, 1658-1669, 2006.

Pietsch, S. A., Hasenauer, H., and Thornton, P. E.: BGC-model parameters for tree species growing in central European forests, Forest Ecol. Manag., 211, 264-295, 2005.

Potter, C., Klooster, S., Nemani, R., Genovese, V., Hiatt, S., Fladeland, M., and Gross, P.: Estimating carbon budgets for U.S. ecosystems, EOS, 87, 1-3, 2006.

Reichstein, M., Ciais, P., Papale, D., Valentini, R., Running, S., Viovy, N., Cramer, W., Granier, A., Ogee, J., Allard, V., Aubinet, M., Bernhofer, C., Buchmann, N., Carrara, A., Grunwald, T., Heimann, M., Heinesch, B., Knohl, A., Kutsch, W., Loustau, D., Manca, G., Matteucci, G., Miglietta, F., Ourcival, J. M., Pilegaard, K., Pumpanen, J., Rambal, S., Schaphoff, S., Seufert, G., Soussana, J. F., Sanz, M. J., Vesala, T., and Zhao, M.: Reduction of ecosystem productivity and respiration during the European summer 2003 climate anomaly: a joint flux tower, remote sensing and modelling analysis, Global Change Biol., 12, 1-18, 2006.

Reichstein, M., Papale, D., Valentini, R., Aubinet, M., Bernhofer, C., Knohl, A., Laurila, T., Lindroth, A., Moors, E., Pilegaard, K., and Seufert, G.: Determinants of terrestrial ecosystem carbon balance inferred from European eddy covariance sites, Geophys. Res. Lett., 34, L01402, doi:10.1029/2006GL, 2007.

Sapsis, D. B. and Kaufmann, J. B.: Fuel consumption and fire behavior associated with prescribed fires in sagebrush ecosystems, Northwest Sci., 65, 173-179, 1991.

Schimel, D., Melillo, J., Tian, H., McGuire, A. D., Kicklighter, D., Kittel, T., Rosenbloom, N., Running, S., Thornton, P., Ojima, D., Parton, W., Kelly, R., Sykes, M., Neilson, R., and Rizzo, B.: Contribution of increasing $\mathrm{CO}_{2}$ and climate to carbon storage by ecosystems in the United States, Science, 287, 2004-2006, 2000. Schulze, E.-D., Wirth, C., and Heimann, M.: Managing forests after 
Kyoto, Science, 289, 2058-2059, 2000.

Smith, J. E. and Heath, L. S.: Carbon stocks and projections on public forestlands in the United States, 1952-2040, Environ. Manage., 33, 433-442, 2004.

Smith, W. B., Miles, P. D., Vissage, J. S., and Pugh, S. A.: Forest Resources of the United States, 2002, GTR-NC-241, U.S.D.A. Forest Service, North Central Research Station, St. Paul MI., 2004.

Smithwick, E. A. H., Harmon, M. E., Remillard, S. M., Acker, S. A., and Franklin, J. F.: Potential upper bounds of carbon stores in forests of the Pacific Northwest, Ecol. Appl., 12, 1303-1317, 2003.

Tatarinov, F. A. and Cienciala, E.: Application of BIOME-BGC model to managed forests. 1. Sensitivity analysis, Forest Ecol. Manag., 237, 267-279, 2006.

Thornton, P. E., Hasenauer, H., and White, M. A.: Simultaneous estimation of daily solar radiation and humidity from observed temperature and precipitation: an application over complex terrain in Austria, Agric. Forest Meteorol., 104, 255-271, 2000.

Thornton, P. E., Law, B. E., Gholz, H. L., Clark, K. L., Falge, E., Ellsworth, D. S., Goldstein, A. H., Monson, R. K., Hollinger, D., Falk, M., Chen, J., and Sparks, J. P.: Modeling and measuring the effects of disturbance history and climate on carbon and water budgets in evergreen needleleaf forests, Agric. Forest Meteorol., 113, 185-222, 2002.

Thornton, P. E. and Running, S. W.: An improved algorithm for estimating incident daily solar radiation from measurements of temperature, humidity, and precipitation, Agric. Forest Meteorol., 93, 211-228, 1999.

Thornton, P. E., Running, S. W., and White, M. A.: Generating surfaces of daily meteorological variables over large regions of complex terrain, J. Hydrol., 190, 214-251, 1997.

Turner, D. P., Cohen, W. B., and Kennedy, R. E.: Alternative spatial resolutions and estimation of carbon flux over a managed forest landscape in Western Oregon, Landscape Ecol., 15, 441-452, 2000.

Turner, D. P., Guzy, M., Lefsky, M., Ritts, W., VanTuyl, S., and Law, B. E.: Monitoring forest carbon sequestration with remote sensing and carbon cycle modeling, Environ. Manage., 4, 457466, 2004.

Turner, D. P., Guzy, M., Lefsky, M.A., Van Tuyl, S., Sun, O., Daly, C., Law. B.E.: Effects of land use and fine-scale environmental heterogeneity on net ecosystem production over a temperate coniferous forest landscape, Tellus B, 55, 657-668, 2003.
Turner, D. P., Koerper, G. J., Harmon, M. E., and Lee, J. J.: A carbon budget for forests of the conterminous United States, Ecol. Appl., 5, 421-436, 1995.

UNFCCC: United Nations Framework Convention on Climate Change. http://www.unfccc.de/resource/conv/index.html, 1992.

USDA: National Agricultural Statistics Service, Published Estimates Database 2001, http://www.nass.usda.gov/index.asp, 2001.

Van Tuyl, S., Law, B. E.,Turner, D. P., and Gitelman, A. I.: Variability in net primary production and carbon storage in biomass across forests - an assessment integrating data from forest inventories, intensive sites, and remote sensing, For. Ecol. Manage., 209, 273-291, 2005

Vogelmann, J. E., Howard, S. M., Yang, L., Larson, C. R., Wylie, B. K., and Van Driel, N.: Completion of the 1990s National Land Cover Data Set for the conterminous United States from Landsat Thematic Mapper data and ancillary data sources, Photogramm. Eng. Rem. S., 67, 650-652, 2001.

Waddell, K. L. and Hiserote, B.: The PNW-FIA Integrated Database User Guide and Documentation: Version 2.0, Forest Inventory and Analysis Program, Pacific Northwest Research Station, Portland, OR, 2005.

Wallin, D. O., Harmon, M. E., and Cohen, W. B.: Modeling regional-scale carbon dynamics in Pacific Northwest Forests, in: Carbon Dynamics of Two Forest Regions: Northwestern Russian and the Pacific Northwest, edited by: Krankina, O. and Harmon, M. E., Springer-Verlag, New York, in press, 2007.

Waring, R. H. and Franklin, J. F.: Evergreen forests of the Pacific Northwest, Science, 204, 1380-1386, 1979.

Westerling, A. L., Hidalgo, H. G., Cayan, D. R., and Swetnam, T. W.: Warming and earlier spring increases western U.S. forest wildfire activity, Science, 313, 940-943, 2006.

White, M. A., Thornton, P. E., Running, S. W., and Nemani, R. R.: Parameterization and sensitivity analysis of the BIOME-BGC terrestrial ecosystem model: net primary production controls, Earth Interact., 4, 1-85, 2000

Woodward, F. I., Lomas, M. R., and Lee, S. E.: Predicting the future productivity and distribution of global terrestrial vegetation, in: Terrestrial Global Productivity, edited by: Roy, J., Saugier, B., and Mooney, A., Academic Press, San Diego, CA, 519-539, 2001. 